\title{
The cytotoxicity of brazilin and derivatives might be due to an inhibition of the c-Src-kinase
}

\author{
Annemarie E. Kramell ${ }^{1, \#}$, Bianka Siewert ${ }^{2, \#, ~ J a n a ~ W i e s e ~}{ }^{1}$, Veronika Temml ${ }^{2}$, Hans-Peter Deigner ${ }^{3}$, \\ Ahmed Al-Harrasi ${ }^{4}$ and René Csuk ${ }^{1, *}$ \\ ${ }^{1}$ Full Address: Martin-Luther-University Halle-Wittenberg, Organic Chemistry, Kurt-Mothes-Str. 2, D-06120 \\ Halle (Saale), Germany \\ ${ }^{2}$ Full Address: University of Innsbruck, Institute of Pharmacy/Pharmacognosy, Center for Chemistry and \\ Biomedicine, Innrain 80 - 82, A-6020 Innsbruck, Austria \\ ${ }^{3}$ Full Address: Furtwangen University, Institute of Precision Medicine, Medical and Life Sciences Faculty, \\ Jakob-Kienzle-Straße 17, D-78054 Villingen-Schwenningen, Germany \\ ${ }^{4}$ Full Address: University of Nizwa, Chair of Oman's Medicinal Plants and Marine Natural Products, P.O. Box \\ 33, PC 616, Birkat Al-Mauz, Nizwa, Sultanate of Oman \\ \# Annemarie E. Kramell and Bianka Siewert contributed equally to this work
}

\begin{abstract}
In this study, several derivatives of brazilin with different lipophilicity were synthesized. The cytotoxic potential of these substances was evaluated in S.R.B. assays. A triacetylated brazilin reaction with $\mathrm{PBr}_{3}$ or $\mathrm{PCl}_{3}$ and a subsequent aqueous workup led to the formation of a phosphorous ester containing two triacetylated brazilin subunits. This compound held unexpected high cytotoxicity. In this study, Brazilin-derived triacetate showed good cytotoxic activity $($ EC50 $=5.2 \mathrm{M})$ concerning A2780 carcinoma cells. The results from docking studies suggest that brazilin's cytotoxicity might be due to an inhibition of a tyrosine kinase in an ATP-competitive manner.
\end{abstract}

Keywords: Brazilin; Sappan wood; Cytotoxicity; Tyrosine kinase inhibition.

\section{Introduction}

Some compounds have been used for many centuries in various applications in different regions of the world. New applications are continually being added, while other uses are almost wholly lost. In this way, some compounds have "survived" for many years. This has undoubtedly also been true for brazilin (1). Brazilin (Fig. 1) is a colorless solid and a precursor for a red dye, brazilein (CI 75280, natural red). It is obtained from tropical hardwoods' heartwood such as Caesalpinia echinata Lamarck, C. sappan L. or Haematoxylum brasiletto Karsten ${ }^{1,2}$. In ancient Turkestan, China, Arabia, and India, extract from the wood has been used to dye textiles ${ }^{3}$. Especially in Japan, this dying predominantly silk was established in the year $820 \mathrm{CE}$ by the Emperor Saga; the colorant was named "koro". It was used as an official colorant to dye ceremonial costumes. This tradition has survived until today ${ }^{3,4}$.
There are also early reports from ancient China of its use as an analgesic ${ }^{2}$. Furthermore, for these wood chips extracts, antibacterial ${ }^{5,6}$, anti-helminthic ${ }^{2}$ and antioxidant ${ }^{7-11}$ activity has been reported. Recently, its binding mechanism and the inhibitory effect on amyloid aggregation has been investigated by a multi-spectroscopic approach ${ }^{12}$. Furthermore, a neuroprotective effect of 1 has been established in a human neuroblastoma model ${ }^{13}$. There are also some reports on the cytotoxic activity of brazilein but less for brazilin ${ }^{11,14-21}$.

Recently, increased efforts have been made to make $\mathbf{1}$ the starting point for developing new drugs to be used as anti-acne ${ }^{2}$, anti-inflammatory ${ }^{22-25}$, hypoglycemic, and vasorelaxant agent ${ }^{26-28}$ or benefiting from its hepatoprotective activity ${ }^{7,30,31}$. All these uses would require permanent medication. 


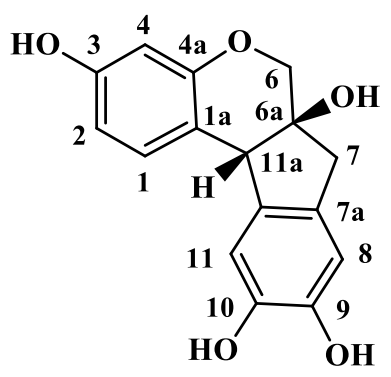

Brazilin (1)

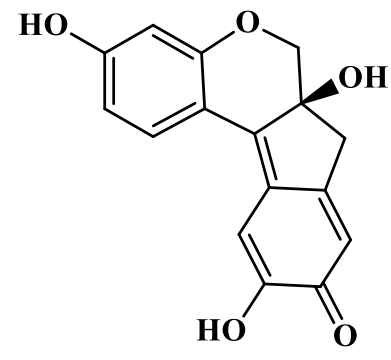

Brazilein

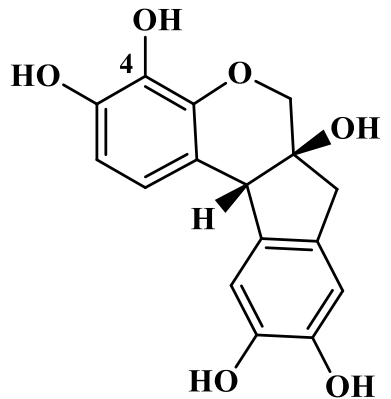

Hematoxylin

Figure 1. Structures of brazilin (1), brazilein, and hematoxylin

This is in contradiction, however, with those publications reporting minor toxic or cytotoxic effects for $\mathbf{1}$. Therefore, we were interested in evaluating the cytotoxic potential of $\mathbf{1}^{18,21}$. To also determine a possible influence of lipophilicity on cytotoxic behavior, different acyl derivatives of $\mathbf{1}$ $\left(\log \mathrm{P}_{\mathrm{o} / \mathrm{w}}=1.51\right)$ were prepared, such as acetates 2 and $3\left(\log \mathrm{P}_{\mathrm{o} / \mathrm{w}}=2.52\right.$ and 3.00$)$, a tris-chloro-acetate $4\left(\log \mathrm{P}_{\mathrm{o} / \mathrm{w}}=3.45\right)$ and a tris-chlorobutyrate 5 $\left(\log \mathrm{P}_{\mathrm{o} / \mathrm{w}}=5.11\right)$.

\section{Results and Discussion}

Sappan wood was obtained from a local supplier. It was shredded and extracted with methanol ${ }^{32}$. The extract was subjected to column chromatography to yield 1 in about $0.7 \%$ based on the amount of wood used. This is in good agreement with previously obtained results on the content of $\mathbf{1}$ in Sappan wood ${ }^{3}$. The compound $\mathbf{1}$ is colorless; however, it oxidizes relatively quickly in the air to red-colored brazilein ${ }^{33,34}$. In some earlier works, this is probably why an off-white or even reddish color of $\mathbf{1}$ was reported, obviously due to a contamination of $\mathbf{1}$ with brazilein. Contaminations of the latter compound in samples of 1 can (besides NMR. spectroscopy, M.S., and T.L.C.) also be easily detected by U.V./Vis spectroscopy. The U.V./Vis spectrum of $\mathbf{1}$ shows the typical $\mathrm{p}$ band for aromatics at $\lambda=289 \mathrm{~nm}$. On the other hand, another band's presence in the visible range at $\lambda=445 \mathrm{~nm}$ would suggest that the obtained brazilin is partly contaminated with brazilein.

Acetylation of $\mathbf{1}$ with acetic anhydride (Scheme 1) yielded the tri-acetate $\mathbf{2}$ whose acetate groups were detected in the ${ }^{1}$ H N.M.R. spectrum ${ }^{35}$ at $\delta=2.20,2.19$ and $2.18 \mathrm{ppm}$, respectively. Acetylation with an excess of acetic anhydride furnished the tetra-acetate 3 in $57.8 \%$ yield whose acetyl groups were detected at $\delta=2.26,2.25,2.23$ and $2.05 \mathrm{ppm}$, respectively. A detailed interpretation of I.R. signals of $\mathbf{1}$ and brazilein has already been reported ${ }^{36}$.
AcO

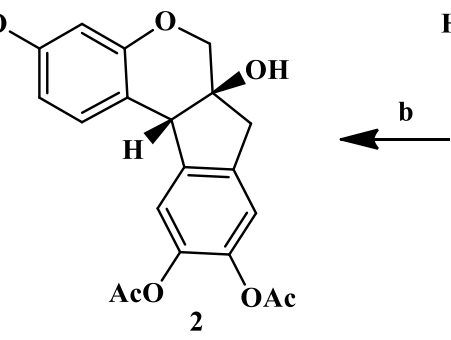

c

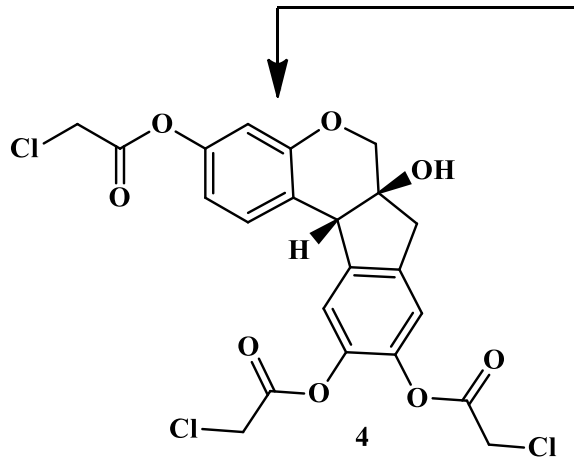

HO<smiles>CO</smiles>

AcO

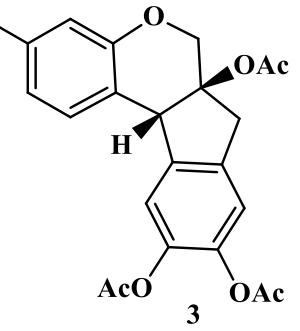

d<smiles>O=C(CCCCl)Oc1ccc2c(c1)OC[C@]1(O)Cc3cc(OC(=O)CCCCl)c(OC(=O)CCCCl)cc3[C@H]21</smiles>

Scheme 1. Reactions and conditions: a. $\mathrm{Ac}_{2} \mathrm{O}$ (excess), $\mathrm{NEt}_{3}, \mathrm{DMAP}$ (cat.), DCM, $23^{\circ} \mathrm{C}, 12 \mathrm{~h}, 57.8 \%$; b. $\mathrm{Ac}_{2} \mathrm{O}$ (excess), $\mathrm{NEt}_{3}$, DMAP (cat.), DCM, $23^{\circ} \mathrm{C}, 24 \mathrm{~h}, 58.4 \%$; c. $\mathrm{ClCH}_{2} \mathrm{COCl}, \mathrm{NEt}_{3}, \mathrm{DCM}, 23^{\circ} \mathrm{C}, 12 \mathrm{~h}, 66 \%$; d. Cl$\left(\mathrm{CH}_{2}\right)_{3}-\mathrm{COCl}, \mathrm{NEt}_{3}, \mathrm{DCM}, 23^{\circ} \mathrm{C}, 12 \mathrm{~h}, 51 \%$ 
Previous studies showed chloro-acetylated compounds are of higher cytotoxicity than their acetylated analogs 37-39. Thus, 3,9,10-tri- $O$ chloroacetyl-brazilin (4) was prepared from $\mathbf{1}$ and chloroacetyl chloride in $66 \%$ isolated yield, while from $\mathbf{1}$ and 4-chlorobutyryl chloride $\mathbf{5}$ was obtained in $51 \%$ yield. The presence of three chlorine substituents was confirmed not only by the results of the corresponding microanalyses, but also by the corresponding isotope distribution patterns of the $[\mathrm{M}+\mathrm{Na}]^{+}$adduct ions detected for $\mathbf{4}$ and $\mathbf{5}$ [for $4 \mathrm{~m} / \mathrm{z} 537.0\left(100 \%,{ }^{35} \mathrm{Cl}^{35} \mathrm{Cl}^{35} \mathrm{Cl}\right), 539.1$ (85\%, for example $\left.{ }^{35} \mathrm{Cl}^{37} \mathrm{Cl}^{35} \mathrm{Cl}\right)$ and 541.0 (28\%, for example ${ }^{37} \mathrm{Cl}^{36} \mathrm{Cl}^{37} \mathrm{Cl}$ were detected)].

The reaction of 2 with $\mathrm{PBr}_{3}$ or $\mathrm{PCl}_{3}$ did not result in the formation of a halogenated product. However, after the usual aqueous workup, phosphorous ester $\mathbf{6}$ (Scheme 2) holding two tri-acetylated brazilin residues was obtained. Its ${ }^{31}$ P N.M.R. chemical shift also characterized this molecule $\delta=0.53 \mathrm{ppm}$ as typical for this compound. At room temperature, $\mathbf{6}$ is a mixture of rotamers leading to a doubling of signals in the respective N.M.R. spectra. On average, the signals differ by about $|\Delta \delta|=0.06 \mathrm{ppm}$ except for $1-\mathrm{H}$ and $7-\mathrm{H}(|\Delta \delta|=0.15 \mathrm{ppm}$ and $|\Delta \delta|=0.21 \mathrm{ppm}$, respectively). Measurements of N.M.R. spectra at elevated temperatures led to a coalescence of the signals. Six acetyl groups' presence also characterizes 6, and ESI-MS experiments show a signal at $\mathrm{m} / \mathrm{z}$ 870.7, corresponding to $[\mathrm{M}+\mathrm{H}]^{+}$. Furthermore, rotations about the central O-P bonds are also hindered due to two bulky residues.

Molecules containing two brazilin subunits are not yet known in the literature. Only a dimeric structure is known, which was created by the reductive coupling of brazilein. Thereby, the coupling of the two subunits took place at position C- ${ }^{40}$.
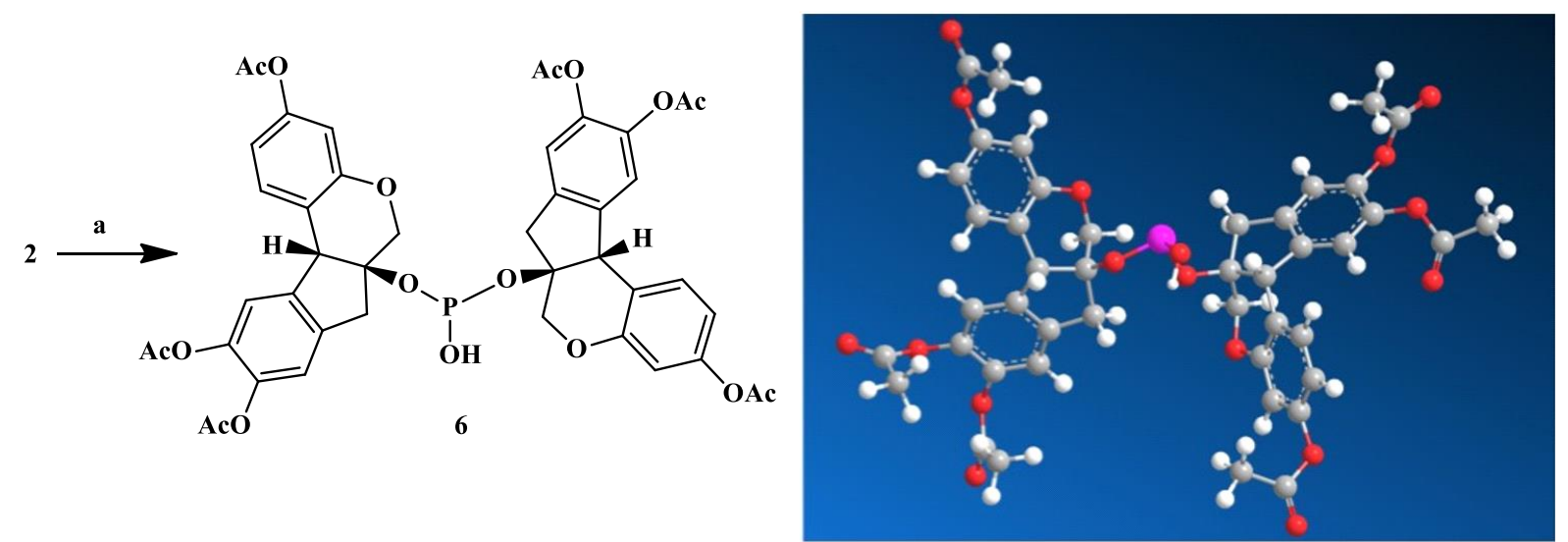

Scheme 2. Synthesis of the phosphorous acid derivative 6 from 2 [a) $\mathrm{PCl}_{3}$, D.C.M., dry pyridine, $0^{\circ} \mathrm{C} \rightarrow 23^{\circ} \mathrm{C}$, $12 \mathrm{~h}, 88 \%$ ], and a ball and stick representation of $\mathbf{6}$ (main conformer, MMFF94 energy minimized; grey: carbon, white: hydrogen, red: oxygen, pink: phosphorus)

Table 1. Cytotoxicity of compounds 1-6 $\left(\mathrm{EC}_{50}\right.$ values in $\mu \mathrm{M}$ from S.R.B. assays after $96 \mathrm{~h}$ of treatment, the values are averaged from three independent experiments performed each in triplicate, confidence interval CI $=95 \%$; mean \pm standard mean error, cut-off $30 \mu \mathrm{M}$ ). Human cancer cell lines: 518A2 (melanoma), A2780 (ovarian carcinoma), HT29 (colorectal adenocarcinoma), MCF-7 (breast adenocarcinoma), A549 (alveolar basal epithelial adenocarcinoma); HeLa (cervical carcinoma), non-malignant: NIH 3 T3 (mouse fibroblasts). Staurosporine (S.T.A.) was used as a positive standard. Tumor cell/non-tumor cell selectivity $\mathrm{S}$ was calculated as $\mathrm{S}=\mathrm{EC}_{50}[\mathrm{NIH}$ 3T3] / $\mathrm{EC}_{50}$ [cell line].

\begin{tabular}{|c|c|c|c|c|c|c|c|}
\hline Compound & 518A2 & A2780 & НТ29 & MCF-7 & A549 & HeLa & NIH 3T3 \\
\hline 1 & $\begin{array}{l}9.4 \pm 1.2 \\
(S=1.4)\end{array}$ & $\begin{array}{l}7.2 \pm 1.1 \\
(\mathrm{~S}=1.8)\end{array}$ & $\begin{array}{c}23.1 \pm 2.0 \\
(\mathrm{~S}=0.6)\end{array}$ & $\begin{array}{c}17.4 \pm 1.9 \\
(\mathrm{~S}=0.7)\end{array}$ & $\begin{array}{l}8.8 \pm 1.4 \\
(S=1.4)\end{array}$ & $\begin{array}{c}17.0 \pm 2.0 \\
(\mathrm{~S}=0.7)\end{array}$ & $12.9 \pm 2.4$ \\
\hline 2 & $\begin{array}{l}8.1 \pm 2.5 \\
(S=1.9)\end{array}$ & $\begin{array}{l}5.2 \pm 1.8 \\
(\mathrm{~S}=2.9)\end{array}$ & $\begin{array}{c}19.6 \pm 2.3 \\
(\mathrm{~S}=0.8)\end{array}$ & $\begin{array}{c}18.8 \pm 3.5 \\
(\mathrm{~S}=0.8)\end{array}$ & $\begin{array}{c}12.7 \pm 2.1 \\
(\mathrm{~S}=1.2)\end{array}$ & $\begin{array}{c}26.4 \pm 2.6 \\
(S=0.6\end{array}$ & $15.0 \pm 2.3$ \\
\hline 3 & $\begin{array}{c}14.3 \pm 0.8 \\
(\mathrm{~S}=1.9)\end{array}$ & $\begin{array}{c}10.1 \pm 1.5 \\
(\mathrm{~S}=2.7)\end{array}$ & $\begin{array}{c}39.4 \pm 4.4 \\
(S=0.7)\end{array}$ & $\begin{array}{c}23.9 \pm 2.4 \\
(\mathrm{~S}=1.1)\end{array}$ & $\begin{array}{c}19.2 \pm 0.5 \\
(\mathrm{~S}=1.4)\end{array}$ & $\begin{array}{c}33.4 \pm 4.0 \\
(\mathrm{~S}=0.8)\end{array}$ & $15.0 \pm 2.3$ \\
\hline 4 & $\begin{array}{l}7.4 \pm 1.0 \\
(\mathrm{~S}=0.4)\end{array}$ & $\begin{array}{l}5.1 \pm 0.7 \\
(\mathrm{~S}=0.5)\end{array}$ & $\begin{array}{c}20.5 \pm 2.4 \\
(S=0.1)\end{array}$ & $\begin{array}{c}14.4 \pm 1.7 \\
(\mathrm{~S}=0.2)\end{array}$ & $\begin{array}{l}7.0 \pm 0.6 \\
(S=0.4)\end{array}$ & $\begin{array}{c}11.9 \pm 1.4 \\
(\mathrm{~S}=0.2)\end{array}$ & $2.7 \pm 0.6$ \\
\hline 5 & $\begin{array}{l}5.6 \pm 1.7 \\
(\mathrm{~S}=1.6)\end{array}$ & $\begin{array}{l}7.9 \pm 1.2 \\
(\mathrm{~S}=1.2)\end{array}$ & $\begin{array}{c}14.9 \pm 1.8 \\
(\mathrm{~S}=1.7)\end{array}$ & $\begin{array}{c}12.2 \pm 1.0 \\
(\mathrm{~S}=0.8)\end{array}$ & $\begin{array}{l}7.3 \pm 1.2 \\
(S=1.3)\end{array}$ & $\begin{array}{c}19.4 \pm 1.7 \\
(\mathrm{~S}=0.5)\end{array}$ & $9.2 \pm 1.3$ \\
\hline 6 & $\begin{array}{c}10.5 \pm 3.3 \\
(S=0.5)\end{array}$ & $\begin{array}{l}3.9 \pm 1.4 \\
(\mathrm{~S}=1.4)\end{array}$ & $\begin{array}{c}18.9 \pm 4.3 \\
(\mathrm{~S}=0.3)\end{array}$ & $\begin{array}{c}17.5 \pm 3.0 \\
(\mathrm{~S}=0.3)\end{array}$ & $\begin{array}{c}11.7 \pm 2.9 \\
(S=0.5)\end{array}$ & $\begin{array}{c}20.4 \pm 3.0 \\
(\mathrm{~S}=0.3)\end{array}$ & $5.6 \pm 1.2$ \\
\hline STA & $\begin{array}{c}0.2 \pm 0.02 \\
(\mathrm{~S}=1.0)\end{array}$ & $\begin{array}{c}0.1 \pm 0.01 \\
(\mathrm{~S}=2.0)\end{array}$ & $\begin{array}{c}0.1 \pm 0.01 \\
(\mathrm{~S}=2.0)\end{array}$ & $\begin{array}{c}0.1 \pm 0.05 \\
(\mathrm{~S}=2.0)\end{array}$ & $\begin{array}{c}0.1 \pm 0.01 \\
(\mathrm{~S}=2.0\end{array}$ & $\begin{array}{c}0.1 \pm 0.02 \\
(\mathrm{~S}=2.0)\end{array}$ & $0.2 \pm 0.02$ \\
\hline
\end{tabular}


To evaluate the compounds' cytotoxicity, sulforhodamine B assays (S.R.B.) were used employing several malignant cell lines and nonmalignant fibroblasts (N.I.H. 3T3) ${ }^{38,39}$. The results from these assays are compiled in Table 1 and depicted in Figure 2.

As a result, the triacetate 2 was - by and large - as cytotoxic as unsubstituted 1. A higher uptake might explain the observed increased activity of 2 due to the greater lipophilicity of $\mathbf{2}$ compared to $\mathbf{1}$. Cytotoxicity dropped, however, significantly for the tetra-acetate $\mathbf{3}$. The tris-chloroacetate 4 was more cytotoxic than the tri-acetate $\mathbf{2}$ but less selective. This is because hydrolysis releases chloroacetic acid, which contributes to increased cellular toxicity. However, higher lipophilicity and thus a possibly increased absorption into the cells cannot be excluded. These findings parallel previous results, having been shown for some pentacyclic triterpenoic acid derivatives ${ }^{41}$. The selectivity to discriminate between tumor cells and non-malignant cells was more or less the same for the tris(chlorobutyryl) derivate $\mathbf{5}$ and unsubstituted $\mathbf{1}$. Unexpected high cytotoxicity $\left(\mathrm{EC}_{50}=3.9 \mu \mathrm{M}\right)$ was observed for $\mathbf{6}$ and A2780 ovarian carcinoma cells. In general, the highest cytotoxicity of all compounds was observed for 518A2 and A2780 and A549 tumor cells. Mouse fibroblasts were also quite sensitive to these compounds except for compounds $\mathbf{2}$ and $\mathbf{3}$.

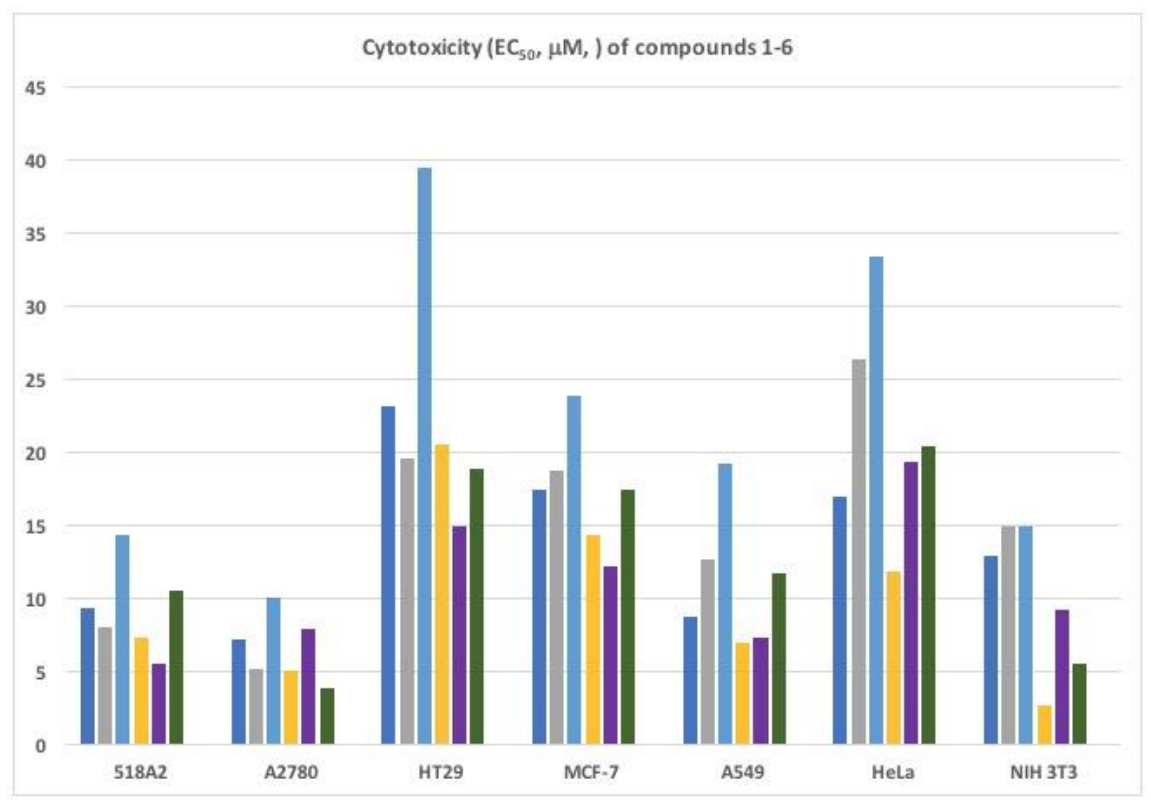

Figure 2. Cytotoxicity ( $\mathrm{EC}_{50}$ in $\mu \mathrm{M}$ from $\mathrm{SRB}$ assay) of compounds $\mathbf{1 - 6}$ [from left to right: $\mathbf{1}$ (dark blue), 2 (grey), $\mathbf{3}$ (light blue), 4 (yellow), $\mathbf{5}$ (pink), $\mathbf{6}$ (green)]

While the mode of action for the chlorinated acyl derivatives $\mathbf{4}$ and $\mathbf{5}$ is likely due to an ability to act as an alkylating agent. A different mechanism might cause the cytotoxicity of 1 . Thus, to reveal 1 and its derivatives' activity, a similarity search was conducted employing the SwissTargetPrediction platform (http://www.swisstargetprediction.ch/). The results from this analysis showed that kinases are most likely targeted by $\mathbf{1}$ and its lipophilic compounds. A 2D similarity search showed that hematoxylin (with an extra hydroxyl group at position 4 compared to 1, Fig. 1), holds a similarity of $82 \%$. Furthermore, hematoxylin is known as a pan-kinase inhibitor causing cell death.

Lin and colleagues ${ }^{42}$ could show that especially the c-Src-kinase ${ }^{43}$ is inhibited by hematoxylin. Utilizing a docking study based on the crystal structure of
c-Src, they conducted that hematoxylin acts by blocking the active binding site due to an interaction with Glu341 and Met343. We were interested in whether brazilin (1) and its derivatives might act similarly from this intriguing observation. Thus, comparative in silico docking experiments were performed. As far as the acylated analogs of brazilin are concerned, we hypothesize that these esters 2-5 might be cleaved ${ }^{44}$ by intracellular ac(et)ylases.

A comparison between hematoxylin and $\mathbf{1}$ revealed that both occupy the same binding pocket and interact with the key residues Glu341 and Met343 at the hinge region of $\mathrm{c}-\mathrm{Src}^{41}$. Additional hydrogen bonds are formed with Ser347 and Asp350 on the other side of the molecule (see Fig. 3). The occupied binding pocket is the adenine pocket of the ATP binding side $^{45}$. 


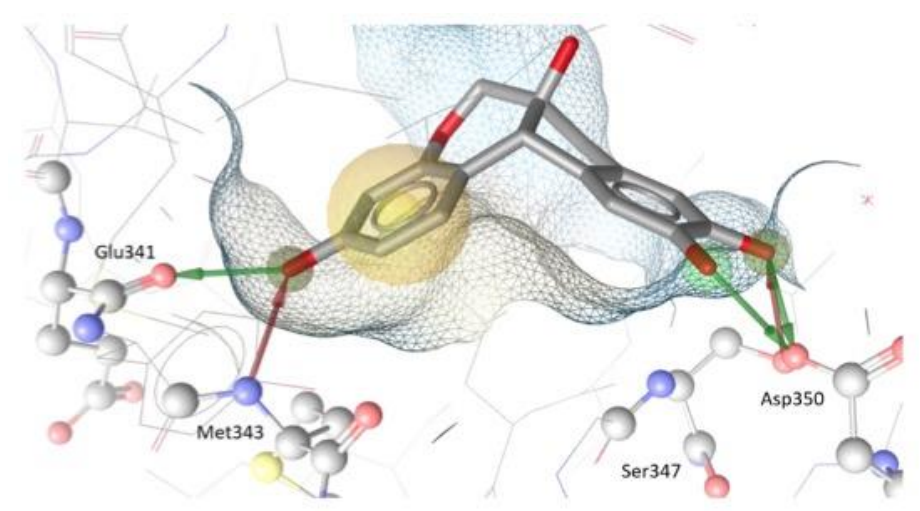

Figure 3. Molecular docking pose of $\mathbf{1}$ in the kinase domain of c-Src. Hydrogen bonds are shown as red and green arrows, hydrophobic contacts as yellow spheres

Thus, one can assume that $\mathbf{1}$, as hematoxylin ${ }^{42}$, wields its tyrosinase kinase inhibitory activity in an ATPcompetitive manner. The c-Src inhibiting action might explain the detected anticancer activity ${ }^{46}$ of $\mathbf{1}$ and its analogs.

\section{Conclusion}

In this study, brazilin was isolated from sappan wood, and several derivatives of brazilin with different lipophilicity were synthesized, e.g., acetyl derivatives. A reaction of the triacetylated brazilin 2 with $\mathrm{PBr}_{3}$ or $\mathrm{PCl}_{3}$ and a subsequent aqueous workup led to the formation of a phosphorous ester containing two triacetylated brazilin subunits. The cytotoxic potential of these substances was evaluated in S.R.B. assays. The phosphorous ester showed unexpected high cytotoxicity $\left(\mathrm{EC}_{50}=3.9 \mu \mathrm{M}\right)$, and the triacetate 2 held good cytotoxicity $\left(\mathrm{EC}_{50}=5.2 \mu \mathrm{M}\right)$ concerning A2780 carcinoma cells. The results from molecular modeling studies suggest that brazilin's cytotoxic activity might be explained by its ability to inhibit a tyrosine kinase in an ATP-competitive manner. The inhibition of c-Src inhibiting and the enzyme tyrosinase ${ }^{47}$ seems thereby of interest and will be investigated in more detail. Future studies will also examine the influence of different substitution patterns and dimeric phosphorous esters' potential.

\section{Acknowledgments}

The authors are grateful to Dr. D. Ströhl, Y. Schiller, and S. Ludwig for multiple N.M.R. spectra and the late Dr. R. Kluge for M.S. measurements. U. Lammel performed elemental analyses and optical rotations, and M. Schneider and S. Ludwig recorded U.V./vis and I.R. spectra. Dr. S. Sommerwerk supported some experiments.

\section{Experimental}

Melting points are uncorrected (Leica hot stage microscope), N.M.R. spectra were recorded using the Varian spectrometers Gemini 2000 or Unity Inova 500 ( $\delta$ are given in ppm, $J$ in $\mathrm{Hz}$; spectra were referenced to residual un-deuterated solvents). The
MS spectra were taken on a Finnigan MAT LCQ (electrospray, spray voltage $4.5 \mathrm{kV}$, sheath gas nitrogen) instrument. For micro-analyses, a FossHeraeus Vario EL (C-HNS) instrument was used. I.R. spectra were measured with a PerkinElmer "Spectrum 1000" FT-IR spectrometer, and U.V./Vis spectra were recorded using a Lambda $750 \mathrm{~S}$ U.V./Vis/N.I.R. spectrophotometer from PerkinElmer. For the determination of the specific optical rotation, a P2000 polarimeter from Jasco was used. T.L.C. was performed on silica gel 60 coated with fluorescent indicator F254 (Merck 5554, detection by U.V. absorption or by treatment with a $10 \%$ sulfuric acid solution, ammonium molybdate cerium(IV) sulfate) followed by gentle heating. Starting materials were obtained from local suppliers in bulk, and the solvents were dried according to usual procedures. The $\log \mathrm{P}_{\mathrm{o} / \mathrm{w}}$ values were calculated using the SwissTargetPrediction platform (http://www.swisstargetprediction.ch/).

\subsection{Cytotoxic evaluation}

The cell lines were obtained from the Department of Oncology (Martin-Luther-University Halle Wittenberg). Cultures were maintained as monolayers in RPMI 1640 medium with L-glutamine (Capricorn Scientific GmbH, Ebsdorfergrund, Germany) supplemented with $10 \%$ heat-inactivated fetal bovine serum (Sigma-Aldrich Chemie $\mathrm{GmbH}$, Steinheim, Germany) and penicillin/streptomycin (1\%, Capricorn Scientific GmbH, Ebsdorfergrund, Germany) at $37^{\circ} \mathrm{C}$ in a humidified atmosphere with $5 \% \mathrm{CO}_{2}$.

The compounds ' cytotoxicity was evaluated using the sulforhodamine-B (Kiton-Red S, A.B.C.R.) microculture colorimetric assay, as previously reported using confluent cells ${ }^{37-39}$.The $\mathrm{EC}_{50}$ values were averaged from three independent experiments performed each in triplicate calculated from semilogarithmic dose-response curves applying a nonlinear Hills-slope equation (GraphPad Prism5; variables top and bottom were set to 100 and 0 , respectively). 


\subsection{Docking simulation}

The molecular docking simulation was carried out with GOLD 5.2 (C.C.D.C., Cambridge, UK). Scoring was calculated using the C.H.E.M.P.L.P. (https://www.ccdc.cam.ac.uk/support-andresources/support/case/?caseid $=5 \mathrm{~d} 1 \mathrm{a} 2 \mathrm{fc} 0-\mathrm{c} 93 \mathrm{a}-$ 49c3-a8e2-f95c472dcff0) scoring function.

PDB entry 1 yom ${ }^{45}$, i.e., the c-Src kinase domain, cocrystalized with the purvalanol B in the ATP binding site, was used as a target structure. The protein was prepared in GOLD, using default settings. The binding site was defined on the A chain in an $8 \AA$ radius at the co-crystalized ligand site. The Protein-ligand interactions of the docking poses were analyzed using LigandScout 4.2 (www.inteligand.com/ligandscout). A re-docking of purvalanol B was conducted to optimize the docking settings. The best-ranked pose with the final docking settings had an R.M.S.D. of 0.711 compared to the cocrystallized ligand.

\section{Brazilin [7,11b-Dihydro-(6aS,11bR) benz [b]indeno[1,2-d]pyran-3,6a,9,10(6H)-tetrol] (1)}

Sappan wood (500 g; Kremer Pigmente $\mathrm{GmbH}$, Aichstetten, Germany) was shredded and extracted with methanol ( $3 \times 5 \mathrm{~L}$, each for 1 day). The solvent was distilled off, and the residue subjected to column chromatography $\left(\mathrm{SiO}_{2}, \mathrm{CHCl}_{3} / \mathrm{MeOH}, 10: 1\right)$ to yield $1(3.3 \mathrm{~g}, 0.7 \%)$ as a colorless solid; m.p. $=157-161^{\circ} \mathrm{C}$ (lit.: $\left.{ }^{48} 156-157^{\circ} \mathrm{C}\right) ;[\alpha]_{D}^{20}=+84^{\circ}(c 0.32, \mathrm{MeOH})$, $\left[\right.$ lit.: $\left.\left.{ }^{49}[\alpha]_{\mathrm{D}}=+90^{\circ}(c) 0.10, \mathrm{MeOH}\right)\right] ; \mathrm{R}_{F}=0.55$ $\left(\mathrm{CHCl}_{3} / \mathrm{MeOH}, 4: 1\right)$;

IR (KBr): $v=3422 \mathrm{br}, 1624 \mathrm{~m}, 1508 \mathrm{~m}, 1464 \mathrm{~m}, 1458 \mathrm{~m}$, $1384 \mathrm{ss}, 1324 \mathrm{~m}, 1302 \mathrm{~m}, 1234 \mathrm{~m}, 1158 \mathrm{~m}, 1116 \mathrm{~m}$, $1072 \mathrm{w}, 1036 \mathrm{~m} \mathrm{~cm}^{-1}$;

$\mathrm{UV} / \mathrm{Vis}(\mathrm{MeOH}): \lambda_{\max }(\log \varepsilon)=289(3.76) \mathrm{nm}$;

${ }^{1} \mathrm{H}$ NMR (500 MHz, CD 3 OD): $\delta=7.18(\mathrm{dd}, \mathrm{J}=8.3$, $0.7 \mathrm{~Hz}, 1 \mathrm{H}, 1-\mathrm{H}), 6.71(\mathrm{~d}, \mathrm{~J}=0.9 \mathrm{~Hz}, 1 \mathrm{H}, 11-\mathrm{H}), 6.60$ (s, 1H, 8-H), 6.47 (dd, J = 8.3, 2.5 Hz, 1H, 2-H), 6.29 $(\mathrm{d}, \mathrm{J}=2.5 \mathrm{~Hz}, 1 \mathrm{H}, 4-\mathrm{H}), 3.96(\mathrm{~s}, 1 \mathrm{H}, 11 \mathrm{~b}-\mathrm{H}), 3.92$ (dd, $\left.\mathrm{J}=11.3,1.4 \mathrm{~Hz}, 1 \mathrm{H}, 6-\mathrm{H}_{\mathrm{a}}\right), 3.69$ (d, J = 11.3 Hz, 1H, 6- $\left.\mathrm{H}_{\mathrm{b}}\right), 3.02\left(\mathrm{~d}, \mathrm{~J}=15.6 \mathrm{~Hz}, 1 \mathrm{H}, 7-\mathrm{H}_{\mathrm{a}}\right), 2.67(\mathrm{~d}, \mathrm{~J}=$ $\left.15.7 \mathrm{~Hz}, 1 \mathrm{H}, 7-\mathrm{H}_{\mathrm{b}}\right) \mathrm{ppm}$;

${ }^{13} \mathrm{C}$ NMR (125 MHz, CD $\left.3 \mathrm{OD}\right): \delta=157.9(\mathrm{C}-3), 155.7$ (C-4a), 145.6 (C-9), 145.3 (C-10), 137.5 (C-11a), 132.2 (C-1), 131.3 (C-7a), 115.6 (C-1a), 112.9 (C-8), 112.4 (C-11), 109.9 (C-2), 104.3 (C-4), 78.1 (C-6a), 70.9 (C-6), 51.1 (C-11b), 42.9 (C-7) ppm;

MS (ESI, MeOH): m/z $285.2\left(66 \%,[\mathrm{M}-\mathrm{H}]^{-}\right), 570.9$ $\left(100 \%,[2 \mathrm{M}-\mathrm{H}]^{-}\right)$;

analysis calcd for $\mathrm{C}_{16} \mathrm{H}_{14} \mathrm{O}_{5}$ (286.28): $\mathrm{C}$ 67.13, $\mathrm{H} 4.93$; found: C 66.87, H 5.11.

\section{3,9,10-Tri- $O$-acetyl-brazilin (2)}

Brazilin (1, $508.9 \mathrm{mg}, 1.8 \mathrm{mmol})$ was suspended in dry DCM $(30 \mathrm{~mL})$, triethylamine $(0.27 \mathrm{~mL}, 2.0$ mmol), acetic anhydride (535.0 $\mathrm{mg}, 5.2 \mathrm{mmol})$ and DMAP (cat.) were added, and the mixture was stirred at $23^{\circ} \mathrm{C}$ for $12 \mathrm{~h}$. Usual aqueous work-up followed by column chromatography $\left(\mathrm{SiO}_{2}\right.$, hexane/ethyl acetate, 1:1) gave 2 (422 mg, 58.4\%) as a colorless solid; m.p.
148-152 ${ }^{\circ} \mathrm{C}$ (lit.: $\left.112^{\circ} \mathrm{C}{ }^{40} ; 105-106{ }^{\circ} \mathrm{C}{ }^{50}\right) ;[\alpha]_{D}^{20}=$ $+65^{\circ}$ (c $0.38, \mathrm{CHCl}_{3}$ ); $\mathrm{R}_{F}=0.30$ (hexane, ethyl acetate, $1: 1)$;

IR $(\mathrm{KBr}): v=3446 \mathrm{br}, 1768 \mathrm{~s}, 1616 \mathrm{w}, 1590 \mathrm{w}, 1498 \mathrm{~m}$, $1488 \mathrm{~m}, 1430 \mathrm{~m}, 1372 \mathrm{~m}, 1214 \mathrm{vs}, 1168 \mathrm{~m}, 1148 \mathrm{~s}$, $1122 \mathrm{~m}, 1070 \mathrm{w}, 1040 \mathrm{~m}, 1014 \mathrm{~m} \mathrm{~cm}^{-1}$; UV/Vis $(\mathrm{MeOH}): \lambda_{\max }(\log \varepsilon)=278(3.72) \mathrm{nm}$;

${ }^{1} \mathrm{H} \mathrm{NMR}\left(500 \mathrm{MHz}, \mathrm{CDCl}_{3}\right): \delta=7.25(\mathrm{dd}, \mathrm{J}=8.4,0.6$ $\mathrm{Hz}, 1 \mathrm{H}, 1-\mathrm{H}), 7.02$ (d, J = 1.1 Hz, 1H, 11-H), 6.94 (s, $1 \mathrm{H}, 8-\mathrm{H}), 6.69$ (dd, J = 8.3, 2.4 Hz, 1H, 2-H, 6.58 (d, $\mathrm{J}=2.2 \mathrm{~Hz}, 1 \mathrm{H}, 4-\mathrm{H}), 4.06(\mathrm{~s}, 1 \mathrm{H}, 11 \mathrm{~b}-\mathrm{H}), 3.91(\mathrm{dd}, \mathrm{J}$ $\left.=11.6,1.5 \mathrm{~Hz}, 1 \mathrm{H}, 6-\mathrm{H}_{\mathrm{a}}\right), 3.7(\mathrm{~d}, \mathrm{~J}=11.5 \mathrm{~Hz}, 1 \mathrm{H}, 6-$ $\left.\mathrm{H}_{\mathrm{b}}\right), 3.09\left(\mathrm{~d}, \mathrm{~J}=16.4 \mathrm{~Hz}, 1 \mathrm{H}, 7-\mathrm{H}_{\mathrm{a}}\right), 2.83(\mathrm{~d}, \mathrm{~J}=16.6$ $\left.\mathrm{Hz}, 1 \mathrm{H}, 7-\mathrm{H}_{\mathrm{b}}\right), 2.20$ (s, 3H, $\left.\mathrm{CH}_{3}\right), 2.19$ (s, 3H, $\mathrm{CH}_{3}$ ), $2.18\left(\mathrm{~s}, 3 \mathrm{H}, \mathrm{CH}_{3}\right) \mathrm{ppm}$;

${ }^{13} \mathrm{C}$ NMR $\left(125 \mathrm{MHz}, \mathrm{CDCl}_{3}\right): \delta=169.33(\mathrm{C}-12)$, 168.43 (C-16), 168.33 (C-14), 154.0 (C-4a), 150.0 (C3), 142.3 (C-11a), 141.22 (C-9), 140.82 (C-10), 137.7 (C-7a), 130.8 (C-1), 120.0 (C-8), 119.2 (C-11), 119.0 (C-1a), 114.7 (C-2), 110.4 (C-4), 76.9 (C-6a), 69.5 (C6), 50.1 (C-11b), 41.2 (C-7), $20.83\left(\mathrm{CH}_{3}\right), 20.43$ $\left(\mathrm{CH}_{3}\right), 20.33\left(\mathrm{CH}_{3}\right) \mathrm{ppm}$;

MS (ESI, MeOH): $m / z 430.1\left(100 \%,\left[\mathrm{M}+\mathrm{NH}_{4}\right]^{+}\right)$, $435.2 \quad\left(19 \%, \quad[\mathrm{M}+\mathrm{Na}]^{+}\right), \quad 444.9 \quad(22 \%$, $\left.[\mathrm{M}+\mathrm{H}+\mathrm{MeOH}]^{+}\right), 846.7\left(14 \%,[2 \mathrm{M}+\mathrm{Na}]^{+}\right)$;

analysis calcd for $\mathrm{C}_{22} \mathrm{H}_{20} \mathrm{O}_{8}$ (412.39): $\mathrm{C} 64.08$, $\mathrm{H} 4.89$; found: C 63.85, H 5.03.

\section{3,6a,9,10-Tetra- $O$-acetyl-brazilin (3)}

To a suspension of brazilin $(\mathbf{1}, 500.0 \mathrm{mg}, 1.8 \mathrm{mmol})$ in dry D.C.M. (35 mL), D.M.A.P. (cat.), triethylamine $(1.25 \mathrm{~mL}, 9.0 \mathrm{mmol})$ and acetic anhydride $(0.76 \mathrm{~mL}$, $8.0 \mathrm{mmol}$ ) were added, and the mixture was stirred at $23^{\circ} \mathrm{C}$ for $12 \mathrm{~h}$. Usual aqueous workup followed by a recrystallization from acetone/water gave $3(460 \mathrm{mg}$, $57.8 \%$ ) as a colorless solid; m.p. $150-151^{\circ} \mathrm{C}$ (lit.. ${ }^{50}$ $\left.149-151^{\circ} \mathrm{C} ; 147.0-148.4^{51}\right) ;[\alpha]_{D}^{20}=+64^{\circ}(c 0.35$, $\left.\mathrm{CHCl}_{3}\right)\left(\right.$ lit. $\left.^{52}[\alpha]_{D}^{20}=+76.4^{\circ}(\mathrm{HOAc})\right) ; \mathrm{R}_{F}=0.64$ (hexane/ethyl acetate, 1:1);

IR $(\mathrm{KBr}): \mathrm{v}=3440 \mathrm{br}, 1770 \mathrm{~s}, 1742 \mathrm{~s}, 1618 \mathrm{w}, 1592 \mathrm{w}$, $1500 \mathrm{~m}, 1490 \mathrm{~m}, 1432 \mathrm{~m}, 1370 \mathrm{~s}, 1324 \mathrm{w}, 1312 \mathrm{w}$, $1210 \mathrm{vs}, 1150 \mathrm{~s}, 1106 \mathrm{~m}, 1070 \mathrm{~m}, 1046 \mathrm{w}, 1014 \mathrm{~m} \mathrm{~cm}^{-1}$; $\mathrm{UV} / \mathrm{Vis}(\mathrm{MeOH}): \lambda_{\max }(\log \varepsilon)=274(3.66)$,

277 (3.67) nm;

${ }^{1} \mathrm{H}$ NMR (500 MHz, DMSO-d 6 ): $\delta=7.59(\mathrm{dd}, \mathrm{J}=8.3$, $0.7 \mathrm{~Hz}, 1 \mathrm{H}, 1-\mathrm{H}), 7.20$ (s, 1H, 8-H), 7.17 (d, J = 1.2 $\mathrm{Hz}, 1 \mathrm{H}, 11-\mathrm{H}), 6.83$ (dd, J = 8.3, $2.4 \mathrm{~Hz}, 1 \mathrm{H}, 2-\mathrm{H}$ ), $6.70(\mathrm{~d}, \mathrm{~J}=2.4 \mathrm{~Hz}, 1 \mathrm{H}, 4-\mathrm{H}), 4.65$ (dd, J = 12.4, 1.8 $\left.\mathrm{Hz}, 1 \mathrm{H}, 6-\mathrm{H}_{\mathrm{a}}\right), 4.59$ (s, 1H, 11b-H), 3.68 (d, J = 12.4 $\left.\mathrm{Hz}, 1 \mathrm{H}, 6-\mathrm{H}_{\mathrm{b}}\right), 3.49$ (d, J = 16.9 Hz, 1H, 7-H), 3.39 (d, $\mathrm{J}=17.2 \mathrm{~Hz}, 1 \mathrm{H}, 7-\mathrm{H}), 2.25\left(\mathrm{~s}, 3 \mathrm{H}, \mathrm{CH}_{3}\right), 2.24(\mathrm{~s}, 3 \mathrm{H}$, $\left.\mathrm{CH}_{3}\right), 2.23\left(\mathrm{~s}, 3 \mathrm{H}, \mathrm{CH}_{3}\right), 2.05\left(\mathrm{~s}, 3 \mathrm{H}, \mathrm{CH}_{3}\right) \mathrm{ppm}$;

${ }^{13} \mathrm{C}$ NMR (125 MHz, DMSO-d 6 ): $\delta=170.23$ (C-18), 169.13 (C-12), 168.33 (C-16), 168.23 (C-14), 153.6 (C-4a), 150.0 (C-3), 141.52 (C-11a), 141.12 (C-9), 140.22 (C-10), 136.8 (C-7a), 131.3 (C-1), 120.4 (C8), 119.0 (C-11), 118.3 (C-1a), 150.3 (C-2), 110.3 (C4), 83.1 (C-6a), 65.3 (C-6), 47.7 (C-11b), 38.8 (C-7), $21.53\left(\mathrm{CH}_{3}\right), 20.83\left(\mathrm{CH}_{3}\right), 20.33\left(\mathrm{CH}_{3}\right), 20.32\left(\mathrm{CH}_{3}\right)$ ppm;

MS (ESI, MeOH): $m / z 472.1\left(60 \%,\left[\mathrm{M}+\mathrm{NH}_{4}\right]^{+}\right), 477.1$ 
$\left(100 \%,[\mathrm{M}+\mathrm{Na}]^{+}\right)$ analysis calcd for $\mathrm{C}_{24} \mathrm{H}_{22} \mathrm{O}_{9}$ (454.43): $\mathrm{C} 63.43, \mathrm{H} 4.88$; found: C 63.11, H 5.01.

\section{3,9,10-Tris- $\boldsymbol{O}$-chloroacetyl-brazilin (4)}

To a suspension of brazilin $(\mathbf{1}, 400 \mathrm{mg}, 1.4 \mathrm{mmol})$ in dry D.C.M. $(15 \mathrm{~mL})$, triethylamine $(1.0 \mathrm{~mL}, 7.2$ mmol) was added; the mixture was cooled to $0^{\circ} \mathrm{C}$, and chloroacetyl chloride $(725 \mathrm{mg}, 6.4 \mathrm{mmol})$ in dry D.C.M. (15 mL) was slowly added, and stirring at $23^{\circ} \mathrm{C}$ was continued for $12 \mathrm{~h}$. Usual aqueous workup followed by column chromatography $\left(\mathrm{SiO}_{2}\right.$, hexane/ethyl acetate, $1: 1)$ gave $4(480 \mathrm{mg}, 66 \%)$ as an off-white oil; $[\alpha]_{D}^{20}=+16^{\circ}\left(c 4.15, \mathrm{CHCl}_{3}\right) ; \mathrm{R}_{F}=0.46$ (hexane/ethyl acetate, 1:1);

IR $(\mathrm{KBr}): v=3442 \mathrm{br}, 2956 \mathrm{w}, 1778 \mathrm{~s}, 1616 \mathrm{~m}, 1594 \mathrm{w}$, $1498 \mathrm{~m}, 1486 \mathrm{~m}, 1430 \mathrm{~m}, 1408 \mathrm{~m}, 1310 \mathrm{~s}, 1282 \mathrm{~m}$, $1242 \mathrm{~s}, 1154 \mathrm{vs}, 1126 \mathrm{vs}, 1040 \mathrm{~m} \mathrm{~cm}^{-1}$;

$\mathrm{UV} / \mathrm{Vis}(\mathrm{MeOH}): \lambda_{\max }(\log \varepsilon)=278(3.79) \mathrm{nm}$;

${ }^{1} \mathrm{H}$ NMR $\left(500 \mathrm{MHz}, \mathrm{CDCl}_{3}\right): \delta=7.33(\mathrm{dd}, \mathrm{J}=8.4,0.6$ $\mathrm{Hz}, 1 \mathrm{H}, 1-\mathrm{H}), 7.12$ (d, J = 1.1 Hz, 1H, 11-H), 7.10 (s, $1 \mathrm{H}, 8-\mathrm{H}), 6.81(\mathrm{dd}, \mathrm{J}=8.3,2.4 \mathrm{~Hz}, 1 \mathrm{H}, 2-\mathrm{H}), 6.70(\mathrm{~d}$, $\mathrm{J}=2.4 \mathrm{~Hz}, 1 \mathrm{H}, 4-\mathrm{H}), 4.28\left(\mathrm{~s}, 2 \mathrm{H}, \mathrm{CH}_{2}(13)\right), 4.25-$ $4.24\left(\mathrm{~m}, 4 \mathrm{H}, 15-\mathrm{H}_{2}+17-\mathrm{H}_{2}\right), 4.18(\mathrm{~s}, 1 \mathrm{H}, 11 \mathrm{~b}-\mathrm{H})$, $4.03\left(\mathrm{dd}, \mathrm{J}=11.6,1.6 \mathrm{~Hz}, 1 \mathrm{H}, 6-\mathrm{H}_{\mathrm{a}}\right), 3.80(\mathrm{~d}, \mathrm{~J}=11.6$ $\left.\mathrm{Hz}, 1 \mathrm{H}, 6-\mathrm{H}_{\mathrm{b}}\right), 3.26\left(\mathrm{~d}, \mathrm{~J}=16.4 \mathrm{~Hz}, 1 \mathrm{H}, 7-\mathrm{H}_{\mathrm{a}}\right), 2.95$ (d, J = $\left.16.6 \mathrm{~Hz}, 1 \mathrm{H}, 7-\mathrm{H}_{\mathrm{b}}\right) \mathrm{ppm}$;

${ }^{13} \mathrm{C}$ NMR $\left(125 \mathrm{MHz}, \mathrm{CDCl}_{3}\right): \delta=166.03(\mathrm{C}-12)$, 165.23 (C-16), 165.13 (C-14), 154.3 (C-4a), 150.0 (C3), 142.9 (C-11a), 140.82 (C-9), 140.52 (C-10), 138.4 (C-7a), 131.3 (C-1), 120.2 (C-8), 119.4 (C-1a), 119.3 (C-11), 114.9 (C-2), 110.6 (C-4), 77.4 (C-6a), 69.9 (C-6), 50.4 (C-11b), 41.2 (C-7), 41.03 (C-13), 40.53 (C-15), 40.53 (C-17) ppm;

MS (ESI, MeOH): $\mathrm{m} / z 537.0\left(100 \%,[\mathrm{M}+\mathrm{Na}]^{+}\right), 539.1$ $\left(85 \%,[\mathrm{M}+\mathrm{Na}]^{+}\right), 541.0\left(28 \%,[\mathrm{M}+\mathrm{Na}]^{+}\right)$; analysis calcd for $\mathrm{C}_{22} \mathrm{H}_{17} \mathrm{O}_{8} \mathrm{Cl}_{3}$ (515.72): $\mathrm{C} 51.24, \mathrm{H}$ 3.32; found: C 50.97, H 3.05.

\section{3,9,10-Tris- $O$-(4-chlorobutyryl)-brazilin (5)}

Following the procedure for the synthesis of $\mathbf{4}$, from 1 (401 mg, $1.4 \mathrm{mmol}$ ) and 4-chlorobutyrylchloride (880 $\mathrm{mg}, \quad 6.4 \mathrm{mmol})$ followed by column chromatography (hexane/ethyl acetate, 1:1) 5 (430 $\mathrm{mg}, 51 \%$ ) was obtained as an off-white oil; $[\alpha]_{D}^{20}=$ $+29^{\circ}\left(c 0.51, \mathrm{CHCl}_{3}\right) ; \mathrm{R}_{F}=0.51$ (hexane/ethyl acetate, $1: 1)$;

IR (KBr): $v=3446 \mathrm{~m}, 2966 \mathrm{w}, 2926 \mathrm{w}, 2870 \mathrm{w}, 1762 \mathrm{vs}$, $1616 \mathrm{~m}, 1592 \mathrm{~m}, 1498 \mathrm{~m}, 1488 \mathrm{~m}, 1440 \mathrm{~m}, 1430 \mathrm{~m}$, $1382 \mathrm{~m}, 1370 \mathrm{~m}, 1310 \mathrm{~s}, 1268 \mathrm{~m}, 1216 \mathrm{~s}, 1150 \mathrm{vs}$, 1126vs, 1040 s cm ${ }^{-1}$;

$\mathrm{UV} / \mathrm{V}$ is $(\mathrm{MeOH}): \lambda_{\max }(\log \varepsilon)=278(3.78) \mathrm{nm}$;

${ }^{1} \mathrm{H}$ NMR (500 MHz, $\left.\mathrm{CDCl}_{3}\right): \delta=7.34(\mathrm{dd}, \mathrm{J}=8.4,0.6$ $\mathrm{Hz}, 1 \mathrm{H}, 1-\mathrm{H}), 7.06$ (d, J = 1.2 Hz, 1H, 11-H), 7.04 (s, $1 \mathrm{H}, 8-\mathrm{H}), 6.79$ (dd, J = 8.3, $2.4 \mathrm{~Hz}, 1 \mathrm{H}, 2-\mathrm{H}), 6.68(\mathrm{~d}$, $\mathrm{J}=2.4 \mathrm{~Hz}, 1 \mathrm{H}, 4-\mathrm{H}), 4.18(\mathrm{~s}, 1 \mathrm{H}, 11 \mathrm{~b}-\mathrm{H}), 4.03$ (dd, J $\left.=11.5,1.6 \mathrm{~Hz}, 1 \mathrm{H}, 6-\mathrm{H}_{\mathrm{a}}\right), 3.82(\mathrm{~d}, \mathrm{~J}=11.5 \mathrm{~Hz}, 1 \mathrm{H}, 6-$ $\left.\left.\mathrm{H}_{\mathrm{b}}\right), 3.67-3.64\left(\mathrm{~m}, 6 \mathrm{H}, 15-\mathrm{H}_{2}\right), 19-\mathrm{H}_{2}, 23-\mathrm{H}_{2}\right), 3.28$ (d, $\left.\left.\mathrm{J}=16.3 \mathrm{~Hz}, 1 \mathrm{H}, 7-\mathrm{H}_{\mathrm{a}}\right)\right), 2.93(\mathrm{~d}, \mathrm{~J}=16.4 \mathrm{~Hz}, 1 \mathrm{H}, 7-$ $\left.\left.\mathrm{H}_{\mathrm{b}}\right), 2.76-2.71\left(\mathrm{~m}, 6 \mathrm{H}, 13-\mathrm{H}_{2}\right), 17-\mathrm{H}_{2}, 21-\mathrm{H}_{2}\right), 2.20$ $2.15\left(\mathrm{~m}, 6 \mathrm{H}, 14-\mathrm{H}_{2}, 18-\mathrm{H}_{2}, 22-\mathrm{H}_{2}\right) \mathrm{ppm}$;

${ }^{13} \mathrm{C}$ NMR (125 MHz, $\left.\mathrm{CDCl}_{3}\right): \delta=171.23(\mathrm{C}-12)$,
170.33 (C-16), 170.23 (C-20), 154.1 (C-4a), 150.1 (C3), 142.2 (C-11a), 141.32 (C-9), 140.92 (C-10), 137.5 (C-7a), 131.1 (C-1), 120.2 (C-8), 119.3 (C-11), 118.9 (C-1a), 115.2 (C-2), 110.7 (C-4), 77.3 (C-6a), 69.9 (C6), 50.4 (C-11b), 43.93 (C-15), 43.83 (C-19), 43.83 (C-23), 41.0 (C-7), 31.33 (C-13), 30.83 (C-17), 30.73 (C-21), 27.53 (C-14), 27.43(C-18), 27.33 (C-22) ppm; MS (ESI, MeOH): $m / z 616.1\left(100 \%,\left[\mathrm{M}+\mathrm{NH}_{4}\right]^{+}\right)$, $621.1\left(78 \%,[\mathrm{M}+\mathrm{Na}]^{+}\right), 623.1\left(64 \%,[\mathrm{M}+\mathrm{Na}]^{+}\right), 625.1$ $\left(20 \%,[\mathrm{M}+\mathrm{Na}]^{+}\right)$;

analysis calcd for $\mathrm{C}_{28} \mathrm{H}_{29} \mathrm{O}_{8} \mathrm{Cl}_{3}$ (599.88): $\mathrm{C} 55.06, \mathrm{H}$ 4.87; found: C 54.84, H 5.00.

\section{(Hydroxyphosphanediyl)bis[oxy(6aS,11bR)-7,11 b-dihydrobenzo $[b]$ indeno $[1,2-d]$ pyran-6a, 3,9,10 (6H)-tetrayl] hexaacetate (6)}

To a suspension of $2(51.3 \mathrm{mg}, 0.12 \mathrm{mmol})$ in dry DCM (3 mL), dry pyridine $(0.05 \mathrm{~mL})$ was added. The mixture was cooled, and at $0^{\circ} \mathrm{C}, \mathrm{PCl}_{3}(0.02 \mathrm{~mL}, 0.21$ mmol) was added. Stirring at $23^{\circ} \mathrm{C}$ was continued for $12 \mathrm{~h}$. Usual aqueous work-up followed by an extraction with diethyl ether $(3 \times 20 \mathrm{~mL})$ and column chromatography $\left(\mathrm{SiO}_{2}\right.$, hexane/ethyl acetate, 1:2) gave $6(62 \mathrm{mg}, 88 \%)$ as a colorless solid; m.p. $149-151^{\circ} \mathrm{C} ;[\alpha]_{D}^{20}=+9^{\circ}\left(c 4.4, \mathrm{CHCl}_{3}\right) ; \mathrm{R}_{F}=0.54$ (hexane/ethyl acetate, 1:2);

IR $(\mathrm{KBr}): \mathrm{v}=3442 \mathrm{~m}, 2930 \mathrm{w}, 1770 \mathrm{vs}, 1618 \mathrm{~m}, 1592 \mathrm{~m}$, $1500 \mathrm{~s}, 1490 \mathrm{~m}, 1430 \mathrm{~m}, 1372 \mathrm{~s}, 1308 \mathrm{~m}, 1272 \mathrm{~m}$, 1210vs, 1170s, 1150s, 1132s, 1070m, 1046m, 1012s, $970 \mathrm{~s} \mathrm{~cm}^{-1}$;

UV/Vis $(\mathrm{MeOH}): \lambda_{\max }(\log \varepsilon)=278(3.87) \mathrm{nm}$;

${ }^{1} \mathrm{H}$ NMR (400 MHz, CDCl3): $\delta=7.29(\mathrm{~d}, \mathrm{~J}=8.4 \mathrm{~Hz}$, $1 \mathrm{H}, 1-\mathrm{H}), 7.14\left(\mathrm{~d}, \mathrm{~J}=8.4 \mathrm{~Hz}, 1 \mathrm{H}, 1^{6}-\mathrm{H}\right), 7.03$ (d, J = $1.1 \mathrm{~Hz}, 1 \mathrm{H}, 11-\mathrm{H}), 7.02-7.01$ (m, 3H, 8-H, 8'-H), $11^{6}$ $\mathrm{H}), 6.80(\mathrm{dd}, \mathrm{J}=8.3,2.3 \mathrm{~Hz}, 1 \mathrm{H}, 2-\mathrm{H}), 6.75(\mathrm{dd}, \mathrm{J}=$ 8.3, $\left.2.3 \mathrm{~Hz}, 1 \mathrm{H}, 2^{6}-\mathrm{H}\right), 6.66$ (d, J = $\left.2.3 \mathrm{~Hz}, 1 \mathrm{H}, 4-\mathrm{H}\right)$, $6.59\left(\mathrm{~d}, \mathrm{~J}=2.3 \mathrm{~Hz}, 1 \mathrm{H}, 4^{6}-\mathrm{H}\right), 4.55-4.42(\mathrm{~m}, 4 \mathrm{H}, 6-$ $\left.\left.\mathrm{H}_{\mathrm{a}}+6^{6}-\mathrm{H}_{\mathrm{a}}+11_{\mathrm{b}}-\mathrm{H}\right)+11 \mathrm{~b}^{\mathrm{c}} \mathrm{H}\right), 3.88-3.75(\mathrm{~m}, 3 \mathrm{H}, 6-$ $\left.\left.\mathrm{H}_{\mathrm{b}}+6^{6}-\mathrm{H}_{\mathrm{b}}\right)+7-\mathrm{Ha}\right), 3.54\left(\mathrm{~d}, \mathrm{~J}=16.3 \mathrm{~Hz}, 1 \mathrm{H}, 7^{6}-\mathrm{H}_{\mathrm{a}}\right)$, $3.16\left(\mathrm{~d}, \mathrm{~J}=9.3 \mathrm{~Hz}, 1 \mathrm{H}, 7-\mathrm{H}_{\mathrm{b}}\right), 3.11(\mathrm{~d}, \mathrm{~J}=9.1 \mathrm{~Hz}, 1 \mathrm{H}$, $\left.7^{6}-\mathrm{H}_{\mathrm{b}}\right), 2.28-2.24\left(\mathrm{~m}, 18 \mathrm{H}, 6 \times \mathrm{CH}_{3}\right) \mathrm{ppm}$;

${ }^{13} \mathrm{C} \mathrm{NMR}\left(100 \mathrm{MHz}, \mathrm{CDCl}_{3}\right): \delta=169.33(\mathrm{C}-12+\mathrm{C}-$ $\left.12^{\circ}\right), 168.43$ (C-16), 168.33 (C-16'), 168.33 (C-14 + C-14'), $153.9\left(\mathrm{C}-4 \mathrm{a}+\mathrm{C}-4 \mathrm{a}^{\circ}\right), 150.7$ (C-3), 150.5 (C$\left.3^{6}\right), 141.9$ (C-11a), $141.9\left(\mathrm{C}-11 \mathrm{a}^{6}\right), 141.62$ (C-9), 141.52 (C-9`), 140.82 (C-10), 140.82 (C-10`), 136.2 (C-7a), 136.1 (C-7a'), 130.8 (C-1), 130.8 (C-1'), 120.4 (C-8), 120.2 (C-8`), 119.5 (C-11), 119.5 (C$\left.11^{\circ}\right), 117.8$ (C-1a), $117.6\left(\mathrm{C}-1 \mathrm{a}^{\circ}\right), 115.5\left(\mathrm{C}-2+\mathrm{C} 2^{\circ}\right)$, 110.8 (C-4), $110.7\left(\mathrm{C}-4^{\circ}\right), 85.8$ (C-6a), $85.7\left(\mathrm{C}^{\circ}-6 \mathrm{a}^{\circ}\right)$, 85.6 (C-6), 85.5 (C-6`), 49.5 (C11-b), 49.4 (C-11b'),

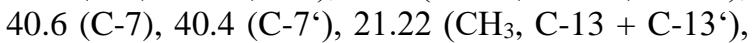
$20.73\left(\mathrm{CH}_{3}, \mathrm{C}-15\right), 20.73\left(\mathrm{CH}_{3}, \mathrm{C}-15^{\circ}\right), 20.73\left(\mathrm{CH}_{3}\right.$, $\mathrm{C}-17), 20.73\left(\mathrm{CH}_{3}, \mathrm{C}-17^{\circ}\right) \mathrm{ppm}$;

${ }^{31} \mathrm{P}$ NMR $\left(162 \mathrm{MHz}, \mathrm{CDCl}_{3}\right): \delta=0.53(\mathrm{~s}, \mathrm{P}-\mathrm{OH}) \mathrm{ppm}$; MS (ESI, MeOH): $m / z 870.7\left(18 \%,[\mathrm{M}+\mathrm{H}]^{+}\right), 887.9$ $\left(35 \%,\left[\mathrm{M}+\mathrm{NH}_{4}\right]^{+}\right), 893.0\left(100 \%,[\mathrm{M}+\mathrm{Na}]^{+}\right), 1763.5$ $\left(15 \%,[2 \mathrm{M}+\mathrm{Na}]^{+}\right)$;

analysis calcd for $\mathrm{C}_{44} \mathrm{H}_{39} \mathrm{PO}_{17}$ (870.74): $\mathrm{C} 60.69 \mathrm{H}$ 4.51; found: C 60.41, H 4.67. 


\section{References}

1- N.P. Nirmal, M.S. Rajput, R.G.S.V. Prasad, M. Ahmad, Brazilin from Caesalpinia sappan heartwood and its pharmacological activities: A review, Asian Pac. J. Trop. Med., 2015, 8, 421-430.

2- R.W. Dapson, C.L. Bain, Brazilwood, sappanwood, brazilin and the red dye brazilein: from textile dyeing and folk medicine to biological staining and musical instruments, Biotech. Histochem., 2015, 90, 401-423.

3- D. Cardon, Natural Dyes: Sources, Tradition, Technology and Science, Archetype Publications Ltd., London, 2007.

4- J.H. Hofenk de Graaff, The Colourful Past: Origins, Chemistry and Identification of Natural Dyestuffs, Abegg-Stiftung and Archetype Publications Ltd., London, 2004.

5- R. Pratt, Y. Yuzuriha, Antibacterial activity of the heartwood of Haematoxylon braziletto, J. Am. Pharm. Assoc., 1959, 48, 69-72.

6- H.X. Xu, S.F. Lee, The antibacterial principle of Caesalpinia sappan, Phytother. Res., 2004, 18, 647-651.

7- C.K. Moon, K.S. Park, S.G. Kim, H.S. Won, J.H. Chung, Brazilin protects cultured rat hepatocytes from bromochloroform-induced toxicity, Drug Chem. Toxicol., 1992, 15, 81-91.

8- B.M. Choi, J.A. Lee, S.S. Gao, S.Y. Eun, Y.S. Kim, S.Y. Ryu, Y.H. Choi, R. Park, D.Y. Kwon, B.-R. Kim, brazilin and the extract from Caesalpinia sappan L. protect oxidative injury through the expression of heme oxygenase-1, BioFactors, 2007, 30, 149-157.

9- B.M. Choi, B.R. Kim, Upregulation of heme oxygenase-1 by brazilin via the phosphatidylinositol 3-kinase/Akt and ERK pathways and its protective effect against oxidative injury, Eur. J. Pharmacol., 2008, 580, 12-18.

10- Y. Sasaki, T. Hosokawa, M. Nagai, S. Nagumo, In vitro study for inhibition of NO production about constituents of Sappan lignum, Biol. Pharm. Bull., 2007, 30, 193-196.

11-C.T. Yen, K. Nakagawa-Goto, T.L. Hwang, P.C. Wu, S.L. Morris-Natschke, W.C. Lai, K.F. Bastow, F.R. Chang, Y.C. Wu, K.H. Lee, Antitumor agents. 271: Total synthesis and evaluation of brazilein and analogs as antiinflammatory and cytotoxic agents, Bioorg. Med. Chem. Lett., 2010, 20, 1037-1039.

12-C. Zhang, J. Zhang, H. Rao, J. Yang, X. Wang, $X$. Peng, Investigation on the interaction of brazilin with bovine serum albumin using multispectroscopic and computational methods: Exploring vthe binding mechanism and inhibitory effect on amyloid aggregation, Microchem. J., 2020, 159, 105529.

13-G. Henriquez, L. Mendez, A. Varela-Ramirez, E. Guerrero, M. Narayan, Neuroprotective effect of brazilin on amyloid b (25-35)-induced pathology in human neuroblastoma model, A.C.S. Omega, 2020, 5, 13785-13792.

14-D.Y. Lee, M.K. Lee, G.S. Kim, H.J. Noh, M.H. Lee, Brazilin inhibits growth and induces apoptosis in human glioblastoma cells, Molecules, 2013, 18, 2449-2457.

15-W.J. Du, J.J. Guo, M.T. Gao, S.Q. Hu, X.Y. Dong, Y.F. Han, F.F. Liu, S. Jiang, Y. Sun, Brazilin inhibits amyloid $\beta$-protein fibrillogenesis, remodels amyloid fibrils and reduces amyloid cytotoxicity, Sci. Rep., 2015, 5, 7992.

16-J. Guo, W. Sun, L. Li, F. Liu, W. Lu, Brazilin inhibits fibrillogenesis of human islet amyloid polypeptide, disassembles mature fibrils, and alleviates cytotoxicity, R.S.C. Adv., 2017, 7, 43491-43501.

17-R.I. Jenie, S. Handayani, R.A. Susidarti, L.Z. Udin, E. Meiyanto, The cytotoxic and antimigratory activity of brazilin-doxorubicin on MCF-7/HER2 cells, Adv. Pharm. Bull., 2018, 8, 507-516.

18-N.P.L. Laksmiani, E.D.Y. Meiyanto, R.A. Susidarti, Cytotoxic activity of brazilein isolated from Secang (Caesalpinia sappan L.) against MCF7/DOX cells by inhibition of

P-glycoprotein, Int. J. Pharm. Pharm. Sci., 2017, 9, 124-130.

19-M. Li, X. Dong, Y. Liu, Y. Sun, Brazilin Inhibits Prostatic Acidic Phosphatase Fibrillogenesis and Decreases its Cytotoxicity, Chem. Asian J., 2017, 12, 1062-1068.

20-F. Liu, Y. Wang, J. Sang, W. Wei, W. Zhao, B. Chen, F. Zhao, L. Jia, F. Lu, Brazilin Inhibits $\alpha$-Synuclein Fibrillogenesis, Disrupts Mature Fibrils, and Protects against Amyloid-Induced Cytotoxicity, J. Agric. Food Chem., 2019, 67, 11769-11777.

21-C. Ngernnak, P. Panyajai, S. Anuchapreeda, W. Wongkham, A. Saiai, Phytochemical and cytotoxic investigations of the heartwood of Caesalpinia sappan linn, Asian J. Pharm. Clin. Res., 2018, 11, 1-4.

22-C.C. Lee, C.N. Wang, J.J. Kang, J.W. Liao, B.L. Chiang, H.C. Chen, C.M. Hu, C.D. Lin, S.H. Huang, Y.T. Lai, Antiallergic Asthma Properties of Brazilin through Inhibition of TH2 Responses in T Cells and in a Murine Model of Asthma, J. Agric. Food Chem., 2012, 60, 9405-9414.

23-S.R. Oh, D.S. Kim, I.S. Lee, K.Y. Jung, J.J. Lee, H.-K. Lee, Anticomplementary activity of constituents from the heartwood of Caesalpinia sappan, Planta Med., 1998, 64, 456-458.

24-C.-M. Hu, Y.-H. Liu, K.-P. Cheah, J.-S. Li, C.-S.K. Lam, W.-Y. Yu, C.-S. Choy, Heme oxygenase-1 mediates the inhibitory actions of brazilin in RAW264.7 macrophages stimulated with lipopolysaccharide, J. Ethnopharmacol., 2009, 121, 79-85.

25-M. Washiyama, Y. Sasaki, T. Hosokawa, 
S. Nagumo, Anti-inflammatory constituents of Sappan Lignum, Biol. Pharm. Bull., 2009, 32, 941-944.

26-C.M. Hu, J.J. Kang, C.C. Lee, C.H. Li, J.W. Liao, Y.W. Cheng, Induction of vasorelaxation through activation of nitric oxide synthase in endothelial cells by Brazilin, Eur. J. Pharmacol., 2003, 468, 37-45.

27-Y. Sasaki, M. Suzuki, T. Matsumoto,

T. Hosokawa, T. Kobayashi, K. Kamata,

S. Nagumo, Vasorelaxant activity of Sappan Lignum constituents and extracts on rat aorta and mesenteric artery, Biol. Pharm. Bull., 2010, 33, 1555-1560.

28-Y.W. Xie, D.S. Ming, H.X. Xu, H. Dong, P.P.H. But, Vasorelaxing effects of Caesalpinia sappan. Involvement of endogenous nitric oxide, Life Sci., 2000, 67, 1913-1918.

29- Y. Yan, Y.C. Chen, Y.H. Lin, J. Guo, Z.R. Niu, L.H. Fang, L. Li, S.B. Wang, G.H. Du, Brazilin isolated from the heartwood of Caesalpinia sappan L induces endothelium-dependent and independent relaxation of rat aortic rings, Acta Pharmacol. Sin., 2015, 36, 1318-1326.

30-H.S. Won, J. Lee, L.Y. Khil, S.H. Chae, M.Y. Ahn, B.H. Lee, J.H. Chung, Y.C. Kim, C.K. Moon, Mechanism of action of brazilin on gluconeogenesis in isolated rat hepatocytes, Planta Med., 2004, 70, 740-744.

31-E.J. You, L.Y. Khil, W.J. Kwak, H.S. Won, S.H. Chae, B.H. Lee, C.K. Moon, Effects of brazilin on the production of fructose-2,6-bisphosphate in rat hepatocytes, J. Ethnopharmacol., 2005, 102, 53-57.

32-G.M. Uddin, C.Y. Kim, D. Chung, K.-A. Kim, S.H. Jung, One-step isolation of sappanol and brazilin from Caesalpinia sappan and their effects on oxidative stress-induced retinal death, B.M.B. Rep., 2015, 48, 289-294.

33-P. Pfeiffer, P. Schneider, Quinoid oxidation products in the brasilin series, J. Prakt. Chem. (Leipzig), 1935, 144, 54-62.

34-R. Robinson, Chemistry of brazilin and hematoxylin, Bull. Soc. Chim. Fr., 1958, 1, 125-134.

35-D.S. Kim, N.I. Baek, S.R. Oh, K.Y. Jung, I.S. Lee, H.K. Lee, N.M.R. assignment of Brazilein, Phytochemistry, 1997, 46, 177-178.

36-L.F.C. de Oliveira, H.G.G.M. edwards, E.S. Velozo, M. Nesbitt, Vibrational spectroscopic study of brazilin and brazilein, the main constituents of brazilwood from Brazil, Vibrat. Spectrosc., 2002, 28, 243-249.

37-R. Csuk, A. Barthel, R. Sczepek, B. Siewert, S. Schwarz, Synthesis, Encapsulation and Antitumor Activity of New Betulin Derivatives, Arch. Pharm., 2011, 344, 37-49.

38-L. Heller, A. Knorrscheidt, F. Flemming, J. Wiemann, S. Sommerwerk, I.Z. Pavel, A. AlHarrasi, R. Csuk, Synthesis and proapoptotic activity of oleanolic acid derived amides, Bioorg. Chem., 2016, 68, 137-151.
39-S. Sommerwerk, L. Heller, J. Kuhfs, R. Csuk, Selective killing of cancer cells with triterpenoic acid amides - The substantial role of an aromatic moiety alignment, Eur. J. Med. Chem., 2016, 122, 452-464.

40-R.H. Jaeger, P.M.E. Lewis, R. Robinson, Reduction of brazilein. Occurrence of reductive coupling, Tetrahedron, 1974, 30, 1295-1300.

41-R. Csuk, B. Siewert, C. Dressel, R. Schäfer, Tormentic acid derivatives: synthesis and apoptotic activity, Eur. J. Med. Chem., 2012, 56, 237-245.

42-L.-G. Lin, H. Xie, H.-L. Li, L.-J. Tong, C.-P. Tang, C.-Q. Ke, Q.-F. Liu, L.-P. Lin, M.-Y. Geng, H. Jiang, W.-M. Zhao, J. Ding, Y. Ye, Naturally Occurring Homoisoflavonoids Function as Potent Protein Tyrosine Kinase Inhibitors by c-Src-Based High-Throughput Screening, J. Med. Chem., 2008, 51, 4419-4429.

43-R.B. Irby, T.J. Yeatman, Role of Src expression and activation in human cancer, Oncogene, 2000, 19, 5636-5642.

44-L.D. Lavis, Ester Bonds in Prodrugs, A.C.S. Chem. Biol., 2008, 3, 203-206.

45-C.B. Breitenlechner, N.A. Kairies, K. Honold, S. Scheiblich, H. Koll, E. Greiter, S. Koch, W. Schäfer, R. Huber, R.A. Engh, Crystal Structures of Active Src Kinase Domain Complexes, J. Mol. Biol., 2005, 353, 222-231.

46-M.M. Massip Copiz, T.A. Santa Coloma, c- Src and its role in cystic fibrosis, European J. Cell Biol., 2016, 95, 401-413.

47-Y. Niu, S. Wang, C. Li, J. Wang, Z. Liu, W. Kang, Effective compounds from Caesalpinia sappan L. on the tyrosinase in vitro and in vivo, Nat. Prod. Commun., 2020, 15 , 1934578 X20920055.

48-M. Sudhakar, P. Krishnaiah, A.L. Rao, D.B. Raju, Antimicrobial guided phytochemical evaluation of the pods of Caesalpinia pulcherrima, Asian J. Chem., 2005, 17, 2353-2358.

49-W. Mar, H.T. Lee, K.H. Je, H.Y. Choi, E.K. Seo, A DNA strand-nicking principle of a higher plant, Caesalpinia sappan, Arch. Pharmacal Res., 2003, 26, 147-150.

50-K. Buchka, A. Erck, Beiträge zur Kenntnis des Brasilins, Ber. Deutsch. Chem. Ges., 1885, 18, 1138-1143.

51-W.J. Kwak, M.H. Kim, S.D. Jeon, L.Y. Khil, S.H. Chae, D. Kim, B.H. Lee, C.K. Moon, Effects of Brx-019 (acetic acid 3,6a,9-triacetoxy6,6a,7,11b-tetrahydro-indeno [2,1-c]chromen-10yl ester), a Brazilin derivative, on $\mathrm{T}$ cell-mediated immune responses in multiple low dose streptozotocin-induced diabetic C57BL/6 male mice, Arzneimittelforschung, 2005, 55, 541-548.

52-J. Herzig, J. Pollak, R. Fischer, W. Kluger, A. Mayrhofer, Über Brasilin und Hämatoxylin, Monatsh. Chem., 1906, 27, 743-771 